\title{
Effect of tannin-rich leaves of oak (Quercus incana) on various microbial enzyme activities of the bovine rumen
}

\author{
By H. P. S. MAKKAR, B. SINGH AND R. K. DAWRA \\ Indian Veterinary Research Institute, Regional Station, Palampur Kangra Valley 176061 , \\ Himachal Pradesh, India
}

(Received 21 October 1987 - Accepted 25 April 1988)

\begin{abstract}
1. The objective of the present experiment was to study the effects of oak (Quercus incana) leaves rich in tannins on various enzyme activities of the bovine rumen.

2. The procedure employed was incubation of tannin-rich, very-low-tannin or virtually tannin-free leaves in nylon-gauze bags in the rumen, and determination of enzyme activities in microbes tightly bound to the solid matrix and in microbes loosely plus tightly attached to the solid matrix.

3. The activities of urease (EC 3.5.1.5), carboxymethylcellulase, glutamate dehydrogenase $(E C 1.4 .1 .2)$ and alanine aminotransferase (glutamic-pyruvic transaminase) $(E C 2.6 .1 .2)$ were significantly lower in the tanninrich group, whereas the activities of glutamate ammonia ligase (glutamine synthetase) (EC 6.3.1.2; both $\gamma$ glutamyltransferase (EC 2.3.2.2) and the forward reaction) were higher in the tannin-rich group. These changes were more marked in micro-organisms tightly bound to the solid matrix than in the more complex microbial compartment.

4. The protein, DNA and RNA contents, and protein: RNA ratio, were significantly lower in the tannin-rich group, whereas no difference was observed for protein: DNA between the groups.

5. Effects of tannin-containing extracts of oak leaves on various rumen enzymes in vitro showed a trend similar to that observed in nylon-gauze bags, suggesting that the changes observed in various compartments were due to the tannins of oak leaves.
\end{abstract}

Tannins are present in oak (Quercus incana) leaves at high concentrations, which affect the availability of nutrients and even produce toxic effects when animals consume high amounts of oak leaves (Negi et al. 1979; Neser et al. 1982; Lohan et al. 1983; Makkar et al. 1987). One of the many factors responsible for these effects could be the inhibition by oak tannins of various enzyme activities of the rumen. A number of studies have been made of the effects of tannins on various enzymes in vitro, including some rumen enzymes (McLeod, 1974; Singleton, 1981; Kumar \& Singh, 1984); however, information on the effects of tannins on various processes in the rumen in vivo and in nylon bags is limited (Lohan et al. 1983). One of the objectives of the present study was to investigate the effects of oak tannins on microbial enzyme activities in nylon-gauze bags incubated in the rumen.

Oak leaves are widely available in hilly regions of India and many other countries. In winter when there is acute fodder shortage in these regions, the oak leaves can provide the bulk of nutrients if a simple and economically viable detannification process is developed. There are possibilities that the treatments used for detannification oxidize or convert tannins into other forms which may interact with nutrients or enzymes and cause adverse effects (Sharma et al. 1977; Price et al. 1980; Kumar \& Singh, 1984). Therefore, it was necessary to develop a model system by which the possible effects of tannins or detannified materials could be predicted. In order to study the effects of oak tannins on rumen enzyme activities and to develop the model, we incubated oak leaves (tannin-rich material) and other tree leaves having low concentrations or virtually no tannins, in nylon bags in the rumen and determined various enzyme activities in the micro-organisms that are tightly bound to the washed solid matrix, and the fraction containing loosely plus tightly bound micro-organisms, corresponding to compartment 3 and compartments $2+3$ respectively (Czerkawski, 1984). 


\section{MATERIALS AND METHODS \\ Nylon bag incubations}

A Jersey bullock $(150 \mathrm{~kg}$ ) with a permanent rumen cannula, maintained on a standard ration of wheat chaff ad lib. and supplemented with a balanced concentrate mixture, was used for the nylon bag $(150 \times 90 \mathrm{~mm}, 35$ (SE 5) $\mu \mathrm{m}$ pore size) incubations. The leaves of oak, khirk (Celtis australis) and bamboo (Dendrocalamus hamiltonii) were dried to a constant weight at $55^{\circ}$ and ground through a $1 \mathrm{~mm}$ screen in a Wiley mill. Samples $(4-5 \mathrm{~g})$ were incubated in the rumen for $48 \mathrm{~h}$. The enzyme activities, microbial protein, DNA and RNA were determined in compartment 3 (particles tightly bound) and compartments $2+3$ (loosely plus tightly attached to the solid matrix). These compartments have been defined as suggested by Czerkawski (1984).

For the analysis of compartments $2+3$, the contents of the nylon bag after incubation in the rumen were transferred to another nylon bag and squeezed until fluid no longer flowed from the bag. To the squeezed material $(2 \mathrm{~g})$ was added $6 \mathrm{ml}$ phosphate buffer $(0.05 \mathrm{M}, \mathrm{pH} 7.0)$ and the mixture was sonicated at $60 \mathrm{~mA}$ (Vibronics Ultrasonic Processor) for $4 \mathrm{~min}$ at about $4^{\circ}$ with intermittent cooling. This procedure of releasing the contents of microbes into the medium was essentially the same as that described by Czerkawski et al. (1984). After sonication, the contents were centrifuged at $25000 \mathrm{~g}$ for $30 \mathrm{~min}$ at $4^{\circ}$. The supernatant fraction was used for the various analyses.

For the determination of activities in compartment 3, the incubated material was transferred into another nylon bag and squeezed as before, then the material was suspended in $25 \mathrm{ml}$ McDougall's buffer in the same bag. The bag was squeezed and another $25 \mathrm{ml}$ McDougall's buffer was added to the same bag. The bag was again squeezed until fluid no longer flowed from the bag. This washed material would have essentially the microbes attached to the matrix and corresponded to compartment 3 (Czerkawski, 1984). To $2 \mathrm{~g}$ of this material, $6 \mathrm{ml}$ phosphate buffer were added. The rest of the procedure (sonication, etc.) was the same as that described for compartments $2+3$.

\section{Enzyme assays}

Urease (EC 3.5.1.5), carboxymethylcellulase (CMCase) and proteolytic activities were measured as described previously (Makkar et al. 1981). Glutaminase (EC 3.5.1.2) and aspartate ammonia lyase (aspartase) (EC 4.3.1.1) were assayed by the method of Griffith \& Carlson (1974). The activities of various dehydrogenases were measured as described by Wallace (1979). The method of Meers et al. (1970) was used to assay both NADH- (EC 1.4.1.14) and NADPH-linked (EC 1.4.1.13) glutamate synthase. Alanine aminotransferase (glutamic-pyruvic transaminase) (EC 2.6.1.2) and aspartate aminotransferase (glutamic-oxaloacetic transaminase $(E C 2.6 .1 .1)$ were measured by the colorimetric assay of Reitman \& Frankel (1974), and glutamate ammonia ligase (glutamine synthetase) (EC $6.3 .1 .2)$ by the method of Bender et al. (1977). All assays were carried out at $37^{\circ}$, except dehydrogenases which were measured at $25^{\circ}$. For all enzyme assays, the rate of product formation under the conditions employed was linear with respect to time and enzyme concentration.

\section{Analytical methods}

The method of Lowry et al. (1951) was used for determination of protein after precipitation with trichloroacetic acid and dissolving the protein in $0 \cdot 1 \mathrm{M}$-sodium hydroxide. Bovine serum albumin (fraction V) was used as a standard.

Nucleic acids were determined by the method of Schneider (1957).

The extracts of leaves were prepared as described by Martin \& Martin (1982). Tannins were measured by the method of the Association of Official Analytical Chemists (1970). 
Table 1. Chemical composition of Quercus incana, Celtis australis and Dendrocalamus hamiltonii leaves $(\mathrm{g} / \mathrm{kg}$ dry matter)

\begin{tabular}{llllllll}
\hline \hline & CP & EE & CF & NFE & Ash & Tannins \\
\hline Q. incana & 114 & 54 & 367 & 417 & 48 & 41 \\
C. australis & 124 & 57 & 146 & 496 & 177 & 0 \\
D. hamiltonii & 138 & 35 & 283 & 389 & 155 & $5 \cdot 6$ \\
\hline
\end{tabular}

CP, crude protein (nitrogen $\times 6 \cdot 25$ ); EE, diethyl ether extract; CF, crude fibre; NFE, N-free extract. The tannin content of $Q$. ilex was $2 \mathrm{~g} / \mathrm{kg}$ dry matter.

The effects of tannin-containing extracts of $Q$. incana and $Q$. ilex on rumen enzymes were studied on cell-free extracts in vitro. The procedures for collection of rumen fluid, isolation of cells from the fluid and sonication of the cells to obtain the cell-free extract for enzyme assays were the same as described previously (Makkar \& Singh, 1987).

The chemical composition of the leaves was determined by the method of the Association of Official Analytical Chemists (1984).

The results were analysed statistically according to Snedecor \& Cochran (1967).

\section{RESULTS}

In order to determine the effects of oak tannins on different metabolic activities of the rumen, initially oak ( $Q$. incana) and khirk ( $C$. australis) leaves were selected for incubation in the rumen. $C$. australis was selected because the chemical composition of its leaves was similar to that of $Q$. incana leaves except for tannins and ash (Table 1). To study the effects of oak tannins our model comprised incubation of $Q$. incana (tannin-rich) and $C$. australis (tannin-free) leaves in nylon bags in the rumen, and comparison of various activities in compartment 3 and compartments $2+3$. The differences observed in these activities could be tentatively attributed to the effects of oak tannins.

Of the hydrolytic enzymes studied, urease and CMCase activities were significantly lower for the $Q$. incana group than the $C$. australis group for compartment 3 ; the differences for compartments $2+3$ were not significant (Table 2 ). Protease activity was significantly lower for both compartment 3 and compartments $2+3$ for $Q$. incana leaves. Aspartate ammonia lyase and glutaminase activities were not detectable (Table 2).

Both NADH- (EC 1.4.1.4) and NADPH-linked (EC 1.4.1.3) glutamate dehydrogenase activities were significantly lower for the $Q$. incana group for compartment 3 . However, for compartments $2+3$, NADPH-linked glutamate dehydrogenase activity did not differ significantly, but a significant difference was observed for the NADH-linked enzyme (Table 3).

The differences for other ammonia-assimilation enzymes, i.e. glutamate ammonia ligase (both $\gamma$-glutamyl transferase $(E C$ 2.3.2.2) and the forward reaction) and alanine aminotransferase, for compartment 3 were also significant. The activities of glutamate ammonia ligase were significantly higher for the tannin-rich group, unlike the other enzymes (Table 3). No significant difference was found for glutamate ammonia ligase for compartments $2+3$, and for aspartate aminotransferase the differences were not significant for both compartments. The activities of alanine dehydrogenase (EC 1.4.1.1; both NADH- and NADPH-linked) and aspartate dehydrogenase (NADH-linked) could not be detected (Table 3).

Nucleic acid contents were also determined in compartment 3 and compartments $2+3$ of both the groups (Table 4), but these compounds could not be detected in compartment 3 . 


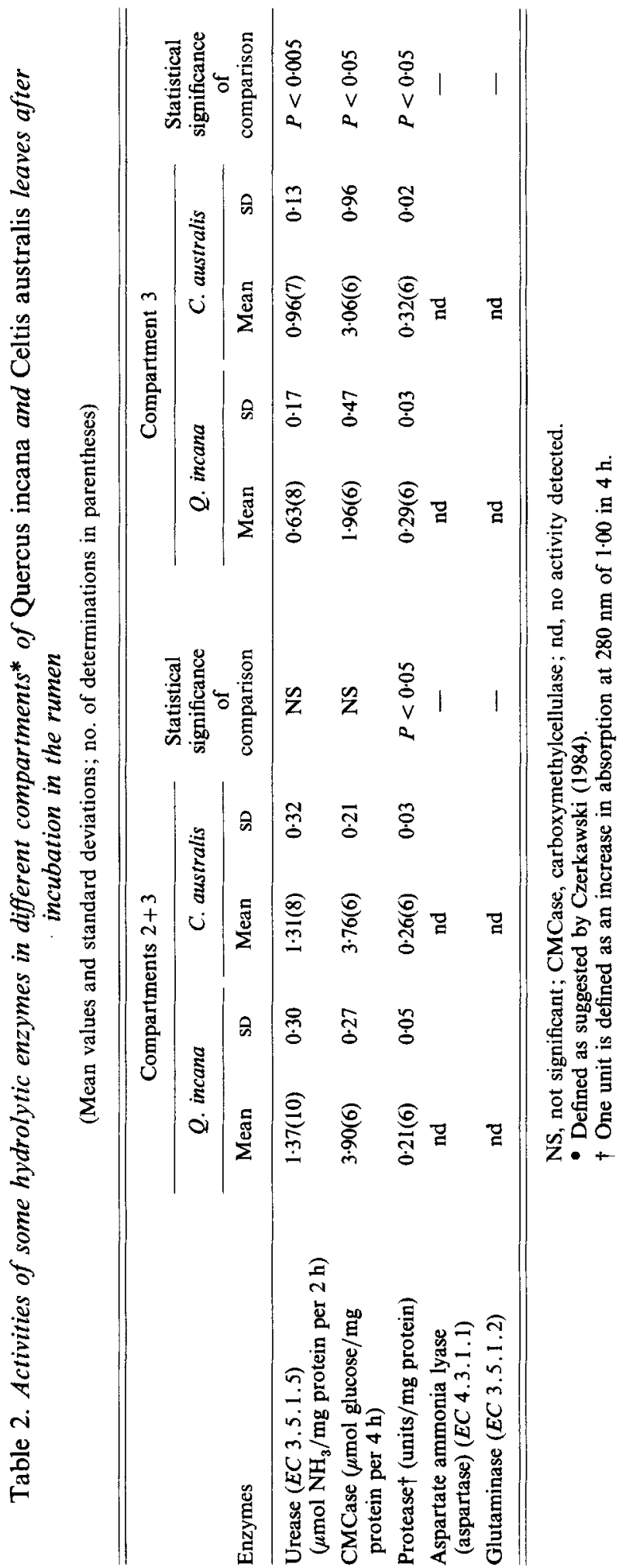


Tannins and enzyme activities of the rumen

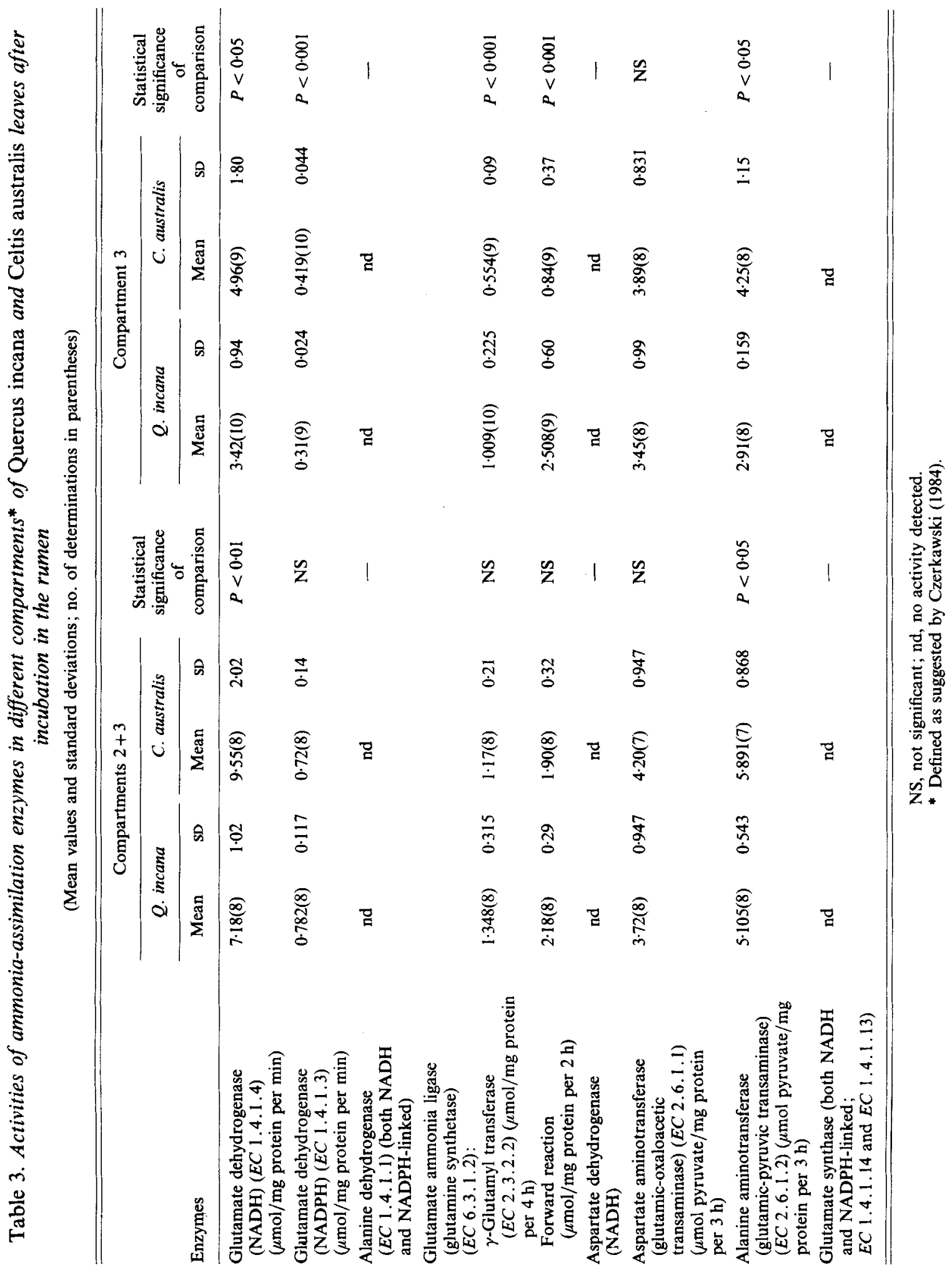




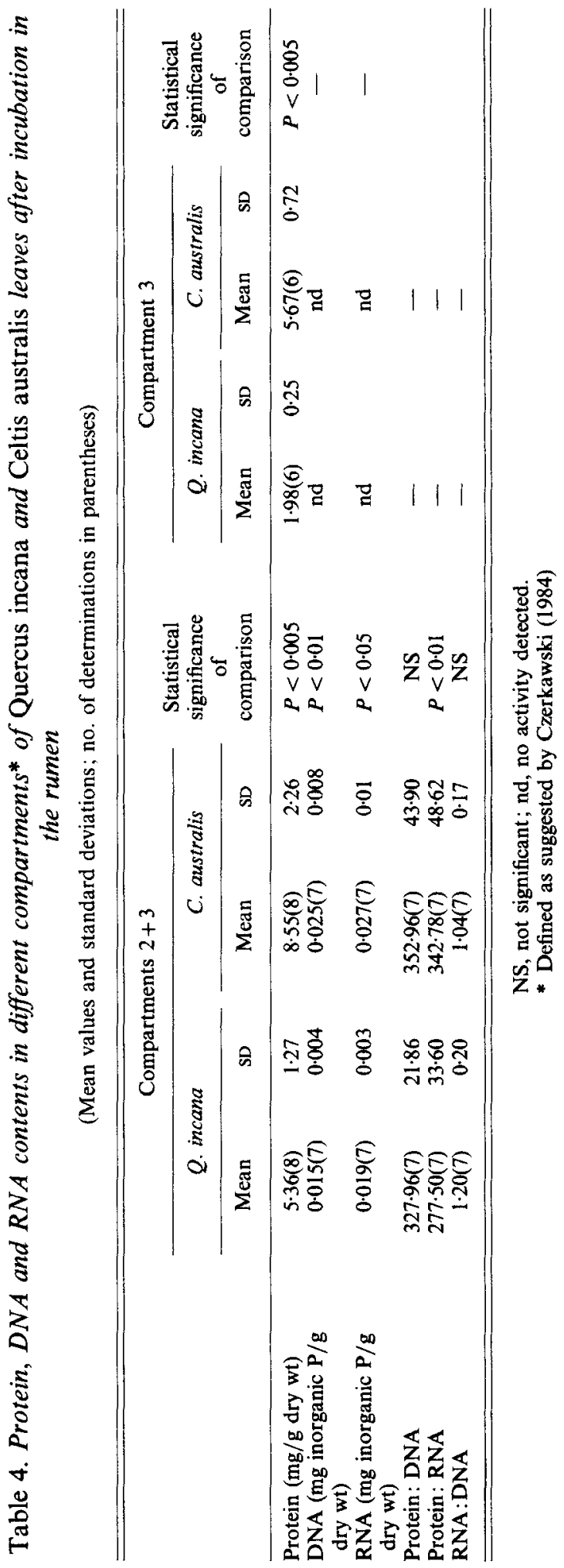


Table 5. Enzyme activities in compartment $3^{*}$ of Quercus incana and Dendrocalamus hamiltonii leaves after incubation in the rumen

(Mean values and standard deviations; no. of determinations in parentheses)

\begin{tabular}{|c|c|c|c|c|c|}
\hline \multirow[b]{2}{*}{ Enzymes } & \multicolumn{2}{|c|}{$Q$. incana } & \multicolumn{2}{|c|}{ D. hamiltonii } & \multirow{2}{*}{$\begin{array}{c}\text { Statistical } \\
\text { significance } \\
\text { of comparison }\end{array}$} \\
\hline & Mean(6) & SD & Mean(6) & SD & \\
\hline $\begin{array}{l}\text { Urease }(E C 3.5 .1 .5) \\
\left(\mu \text { mol } \mathrm{NH}_{3} / \mathrm{mg} \text { protein per } 2 \mathrm{~h}\right)\end{array}$ & 0.584 & 0.09 & 0.828 & 0.06 & $P<0.005$ \\
\hline $\begin{array}{l}\text { CMCase } \\
(\mu \mathrm{mol} \text { glucose } / \mathrm{mg} \text { protein per } 2 \mathrm{~h})\end{array}$ & $2 \cdot 19$ & 0.50 & 3.50 & 1.09 & $P<0.05$ \\
\hline Protease $\uparrow$ (units/mg protein) & 0.27 & 0.05 & 0.32 & 0.046 & NS \\
\hline $\begin{array}{l}\text { Glutamate dehydrogenase (NADH) } \\
(E C 1.4 .1 .4)(\mu \mathrm{mol} / \mathrm{mg} \text { protein per } \mathrm{min})\end{array}$ & $3 \cdot 34$ & 0.47 & $4 \cdot 17$ & 0.92 & $P<0.05$ \\
\hline $\begin{array}{l}\text { Glutamate dehydrogenase (NADPH) } \\
(E C 1.4 .1 .3)(\mu \mathrm{mol} / \mathrm{mg} \text { protein per } \mathrm{min})\end{array}$ & $0 \cdot 40$ & 0.07 & 0.425 & 0.05 & NS \\
\hline \multirow{3}{*}{$\begin{array}{l}\text { Glutamate ammonia ligase (glutamine } \\
\text { synthetase) }(E C 6.3 .1 .2): \\
\gamma \text {-Glutamyl transferase }(E C 2.3 .2 .2) \\
(\mu \text { mol } / \text { mg protein per } 4 \mathrm{~h}) \\
\text { Forward reaction } \\
(\mu \mathrm{mol} / \mathrm{mg} \text { protein per } 2 \mathrm{~h})\end{array}$} & & & & & \\
\hline & 0.73 & $0 \cdot 10$ & 0.64 & 0.04 & $P<0.05$ \\
\hline & $2 \cdot 37$ & 0.59 & $1 \cdot 52$ & 0.23 & $P<0.001$ \\
\hline $\begin{array}{l}\text { Alanine aminotransferase } \\
\text { (glutamic-pyruvic transaminase) } \\
(E C 2.6 .1 .2)(\mu \text { mol pyruvate } / \mathrm{mg} \\
\text { protein per } 2 \mathrm{~h})\end{array}$ & 2.34 & $0 \cdot 49$ & 3.68 & 1.03 & $P<0.001$ \\
\hline
\end{tabular}

NS, not significant; CMCase, carboxymethylcellulase.

* Defined as suggested by Czerkawski (1984).

$\uparrow$ One unit is defined as an increase in absorption at $280 \mathrm{~nm}$ of 1.00 in $4 \mathrm{~h}$.

A significant difference was recorded for protein:RNA ratio between the two groups; however, there was no difference in protein: DNA (Table 4). A significant decrease was also observed in microbial protein in compartment 3 and compartments $2+3$ for the $Q$. incana group (Table 4).

These results suggested that the differences observed in various activities in the two groups could be due to tannins present in oak leaves. However, the effects of some other constituents of the leaves on these activities could not be ruled out. To obtain supporting evidence for these observations similar experiments were carried out, incubating leaves of $Q$. incana and bamboo ( $D$. hamiltonii). The chemical composition of $D$. hamiltonii is given in Table 1. The major difference between the leaves of $Q$. incana and $D$. hamiltonii was in the tannin content. The tannin level in $D$. hamiltonii was slightly higher than that of $C$. australis but was much lower than that in $Q$. incana (Table 1). Significant differences were observed for urease, CMCase, glutamate dehydrogenase (NADH-linked), glutamate ammonia ligase (both $\gamma$-glutamyl transferase and forward reaction) and alanine aminotransferase in compartment 3 (Table 5).

The effects of tannin-containing extracts of $Q$. incana and $Q$. ilex on rumen enzymes were studied in vitro. The activities of urease, CMCase, protease, glutamate dehydrogenase (both NADH- and NADPH-linked) and alanine aminotransferase were inhibited increasingly with increasing quantities of the extract of $Q$. incana leaves in the asssay mixture. The amount of extract required to inhibit aspartate aminotransferase was higher (Table 6). Glutamine synthetase (forward reaction) was activated by up to $200 \mu \mathrm{l}$ of the 
Table 6. Effect of different quantities of extracts of Quercus incana leaves on various enzymes of the rumen* $\dagger$

(Mean values for at least three determinations)

\begin{tabular}{|c|c|c|c|}
\hline \multirow[b]{2}{*}{ Amounts of extract $(\mu l) \ldots$} & \multicolumn{3}{|c|}{ Inhibition (\%) } \\
\hline & 100 & 200 & 300 \\
\hline \multicolumn{4}{|l|}{ Hydrolytic enzymes } \\
\hline Urease (EC 3.5.1.5) & 29 & 56 & 63 \\
\hline Protease & 21 & 32 & 40 \\
\hline Carboxymethylcellulase & 24 & 35 & 36 \\
\hline \multicolumn{4}{|l|}{ Ammonia-assimilating enzymes } \\
\hline $\begin{array}{l}\text { Glutamate dehydrogenase } \\
\text { (NADH) (EC 1.4.1.4) }\end{array}$ & 27 & 53 & 80 \\
\hline $\begin{array}{l}\text { Glutamate dehydrogenase } \\
\text { (NADPH) }(E C \text { 1.4.1.3) }\end{array}$ & 32 & 60 & 80 \\
\hline $\begin{array}{l}\text { Alanine aminotransferase } \\
\text { (glutamic-pyruvic transaminase) } \\
\text { (EC 2.6.1.2) }\end{array}$ & 18 & 32 & 35 \\
\hline $\begin{array}{l}\text { Aspartate aminotransferase } \\
\text { (glutamic-oxaloacetic transaminase) } \\
\text { (EC 2.6.1.1) }\end{array}$ & 0 & 2 & 17 \\
\hline \multicolumn{4}{|l|}{$\begin{array}{l}\text { Glutamate ammonia ligase } \\
\text { (glutamine synthetase) } \\
(\text { EC 6.3.1.2): }\end{array}$} \\
\hline Forward reaction & -19 & -19 & 3 \\
\hline $\begin{array}{l}\gamma \text {-Glutamyl transferase } \\
(E C \text { 2.3.2.2) }\end{array}$ & -14 & -32 & -6 \\
\hline
\end{tabular}

* The extracts used in these studies were prepared according to Martin \& Martin (1982) except that the final volume was kept to $10 \mathrm{ml}$. Amounts of dried leaves extracted were $240 \mathrm{mg}$. Tannin content (as total phenols) of the $Q$. incana extract was $0.888 \mathrm{mg}$ tannic acid equivalent $/ \mathrm{ml}$ and the condensed tannins were $0.405 \mathrm{mg}$ catechin equivalent $/ \mathrm{ml}$, whereas for $Q$. ilex leaves these values were $0.48 \mathrm{mg} / \mathrm{ml}$ and $0.045 \mathrm{mg} / \mathrm{ml}$ respectively.

$\dagger Q$. ilex was also tested, but only the highest amounts of extract $(300 \mu \mathrm{l})$ gave very small inhibition $(5-8 \%$ with some enzymes). Values were: urease 6 , glutamate dehydrogenase (NADH) 5 , glutamate dehydrogenase (NADPH) 8 , alanine aminotransferase 8 .

extract in the assay mixture and above this level the activation was found to decrease. A similar trend was obtained for the $\gamma$-glutamyl transferase reaction of glutamate ammonia ligase (Table 6).

\section{DISCUSSION}

Most of the enzyme activities were lower for both compartment 3 and compartments $2+3$ for the tannin-rich $Q$. incana leaves compared with $C$. australis leaves, except for glutamate ammonia ligase. The apparent stimulation of this enzyme is interesting to note.

The significant difference in protein: RNA ratio between the two groups (Table 4) suggested that oak tannins may decrease RNA synthesis of rumen microbes. DNA synthesis did not appear to be affected. Tannins in the diet have also been reported to decrease microbial DNA and RNA in the rumen (Sadanandan \& Arora, 1979). A significant decrease observed in protein in compartment 3 and compartments $2+3$ in the oak group (Table 4) indicated that tannins might inhibit the process of microbial attachment/adhesion to the feed particles.

The differences observed in various enzyme activities were more marked in compartment 3 compared with those in compartments $2+3$. These differences could be attributed to closer proximity of enzymes/microbes to tannins. In compartment 3 , where the microbes 
are tightly bound to the solid matrix/feed particles, the effects of tannins are expected to be greater compared with those in compartments $2+3$, where dilution of tannins decreases their effects.

In the present study (Q. incana $v$. $C$. australis) significant differences were observed for urease, CMCase, protease, glutamate dehydrogenase (NADH- and NADPH-linked), glutamate ammonia ligase (both $\gamma$-glutamyl transferase and the forward reaction) and alanine aminotransferase, and the differences were more marked in compartment 3. Therefore, the previously mentioned enzymes were assayed only for compartment 3 after incubation in the rumen, but in different sets of leaves: $Q$. incana and $D$. hamiltonii. $D$. hamiltonii leaves served as a control because the tannin content was low in these leaves. The results obtained (Table 5) were similar to those found previously (Tables 2 and 3). It could be inferred from the findings from the two different sets of leaves that the changes observed could be due to the tannins of oak leaves.

Findings relating to the effects of tannin-containing extracts on various rumen enzymes in vitro showed a trend similar to that observed when oak leaves were incubated in the nylon bags. Activities of urease, CMCase, protease, glutamate dehydrogenase and alanine aminotransferase decreased, whereas with glutamate ammonia ligase the enzyme activity increased and then decreased (Table 5). No such effects were observed with the extracts of $Q$. ilex which has very low levels of tannins. Tannins have been shown to inhibit enzymes from various sources (Singleton, 1981; Reddy et al. 1985). The mechanism by which tannins inhibit or stimulate any enzyme could be explained by a change in the conformation of the enzyme in the presence of tannins, so as to increase or decrease the availability of substrate at the catalytic site of the enzyme. Binding of tannins to glutamate ammonia ligase, up to a certain limit, might produce conformational changes in the enzyme which could expose the catalytic sites of the enzyme to a greater extent to the substrate. The activation of proteolytic hydrolysis of various proteins by tannins has also been demonstrated and is considered to be due to tannin-induced conformational changes in the substrate protein (Mole \& Waterman, 1985; Oh \& Hoff, 1986). It would be interesting to investigate: (1) whether the activation of rumen glutamate ammonia ligase is specific for oak tannins or whether any tannin would produce this effect, and (2) the mechanism of activation of rumen glutamate ammonia ligase by oak tannins.

The findings suggest that the changes in the various enzyme activities in compartment 3 and compartments $2+3$ with oak leaves incubated in the rumen are due to the presence of tannins. It is possible that the urease, CMCase, glutamate dehydrogenase (NADH-linked), alanine aminotransferase and glutamate ammonia ligase could be used as biological markers for the effects of oak tannins on the rumen. Measurements of these activities in compartment 3 would give a better reflection of the effect of oak tannins on microbial activities in the rumen. There are a number of reports (Sharma et al. 1977; Price et al. 1980) of chemical methods of tannin determination which showed that although the material had been detannified, when fed it produced deleterious effects. If the changes observed in the present study are due to tannins in oak leaves, the removal or inactivation of tannins from oak leaves should result in no changes being observed. Therefore, comparison of these biological markers in compartment 3 after incubation with the detannified leaves and with the original oak leaves in nylon bags in the rumen, together with the usual methods of tannin determination, would give a better insight into the efficiency of any detannification process. However, this model cannot predict postrumen effects of any tannin-rich or detannified material.

It is evident from the findings of the present study that most of the microbial activities were inhibited by oak tannins. A decrease in the activities of urease and protease associated with oak tannins has also been recorded in vivo (Lohan et al. 1983). Therefore, when oak 
leaves are fed to livestock the enzymic apparatus of the rumen would be expected to operate at a suboptimal level, which will have adverse effects on the animal.

The authors thank the Director of the Institute and Scientist-in-Charge of the Regional Station for facilities.

\section{REFERENCES}

Association of Official Analytical Chemists (1970). Official Methods of Analysis, 11th ed. Washington, DC: Association of Official Analytical Chemists.

Association of Official Analytical Chemists (1984). Official Methods of Analysis, 14th ed. Virginia, USA: Association of Official Analytical Chemists.

Bender, R. A., Janssen, K. A., Resnick, A. D., Blumenberg, M., Foor, F. \& Magasanik, B. (1977). Journal of Bacteriology 129, 1001-1009.

Czerkawski, J. W. (1984). Proceedings of the Nutrition Society 43, 101-118.

Czerkawski, J. W., Piatkova, M. \& Breckenridge, G. (1984). Journal of Applied Bacteriology 56, 81-94.

Griffith, C. J. \& Carlson, J. (1974). Journal of General Microbiology 82, 253-260.

Kumar, R. \& Singh, M. (1984). Journal of Agricultural and Food Chemistry 32, 447-453.

Lohan, O. P., Lall, D., Vaid, J. \& Negi, S. S. (1983). Indian Journal of Animal Science 53, 1057-1063.

Lowry, O. H., Rosebrough, N. J., Farr, A. L. \& Randall, R. J. (1951). Journal of Biological Chemistry 193, $262-275$

McLeod, M. N. (1974). Nutrition Abstracts and Reviews 44, 803-815.

Makkar, H. P. S., Sharma, O. P., Pal, R. N. \& Negi, S. S. (1981). Journal of Dairy Science 63, 785-788.

Makkar, H. P. S. \& Singh, B. (1987). Journal of Applied Rabbit Research 10, 172-174.

Makkar, H. P. S., Singh, B. \& Dawra, R. K. (1987). International Journal of Animal Science 2, 127-140.

Martin, J. S. \& Martin, M. M. (1982). Oecologia 5, 205-211.

Meers, J. L., Tempest, D. W. \& Brown, C. M. (1970). Journal of General Microbiology 64, 187-194.

Mole, S. \& Waterman, P. G. (1985). Journal of Chemical Ecology 11, 1323-1332.

Negi, S. S., Pal, R. N. \& Ehrich, C. (1979). Tree Fodders in Himachal Pradesh, no. 41, Eschborn, FRG: German Agency for Technical Cooperation.

Neser, J. A., Coetzer, J. A. W., Boomker, J. \& Cable, H. (1982). Journal of South African Veterinary Association $53,151-155$.

Oh, H. I. \& Hoff, J. E. (1986). Nutrition Reports International 34, 51-58.

Price, M. L., Hagerman, A. E. \& Butler, L. G. (1980). Nutrition Reports International 21, 761-767.

Reddy, N. R., Pierson, M. D., Sathe, S. K. \& Salunkhe, D. K. (1985). Journal of the American Oil Chemists' Society 62, 541-549.

Reitman, S. \& Frankel, S. (1974). In Methods of Enzymatic Analysis, vol 2, pp. 735, 760 [H. U. Bergmeyer, editor]. London: Academic Press.

Sadanandan, K. P. \& Arora, S. P. (1979). Journal of Nuclear and Agriculture Biology 8, 1-3.

Schneider, W. C. (1957). Methods in Enzymology, vol. 3, p. 680, New York: Academic Press.

Sharma, K., Wah, C. S. \& Jackson, M. G. (1977). Indian Journal of Animal Science 47, 473-478.

Singleton, V. L. (1981). Advances in Food Research 27, 149-242.

Snedecor, G. W. \& Cochran, W. G. (1967). Statistical Methods. Ames, Iowa: The Iowa State University Press.

Wallace, R. J. (1979). Journal of Applied Bacteriology 47, 443-445. 